\title{
Digital learning environments
}





\title{
Mobile Technology and Science Outreach in Archaeology: Integrating Didactics
}

\author{
David Frederik Hölscher
}

KiSOC - Kiel Science Outreach Campus a joint venture of Kiel University

(Institute of Pre- and Protohistoric Archaeology) and the IPN - Leibniz

Institute for Science and Mathematics Education

\begin{abstract}
This contribution outlines approaches to the integration of didactic principles and educational research into science outreach in archaeology and cultural heritage. The focus lies on the target group's conceptions prior to involvement with the outreach programme and the development of learning objectives. The chapter gives insights into the author's PhD project at Kiel Science Outreach Campus, a joint venture of Kiel University and Leibniz Gemeinschaft. The project combines an educational research agenda with the development of a mobile learning environment including elements of spatial games on basis of didactic principles. The chapter concludes with a demand for a more frequent application of didactic principles by those who are involved in the planning and implementation of public outreach in archaeology and cultural heritage as well as for the consideration of the boundaries of scientific knowledge in connection with outreach activities.
\end{abstract}

How to cite this book chapter:

Hölscher, D. F. 2020. Mobile Technology and Science Outreach in Archaeology: Integrating Didactics. In: Hageneuer, S. (ed.) Communicating the Past in the Digital Age: Proceedings of the International Conference on Digital Methods in Teaching and Learning in Archaeology (12-13 October 2018). Pp. 155-166. London: Ubiquity Press. DOI: https://doi.org/10.5334/bch.l. License: CC-BY 4.0 


\section{Keywords}

Science Outreach, Human-Environment Interaction, Public Archaeology, Educational Research, Outdoor Learning

\section{Introduction: digital science outreach and didactics in European archaeology today}

Archaeological topics and research are brought to the public's attention by many formats. Among the most important are exhibitions and educational programmes in museums as well as radio and television broadcasts (see Bonacchi 2014). As - in Central Europe at least - archaeology is almost absent from school education, informal learning opportunities are the most significant way of gaining archaeological knowledge outside higher education. In the course of rapid technological development, especially in the digital sector, multimedia formats have been included in informal learning settings. In recent years, a vast number of multimedia guides and especially mobile applications have been developed concerning cultural heritage in general and in some cases archaeological topics in particular. ${ }^{1}$ Examples are the offline mobile app 'Limes Mittelfranken Mobil' from southern Germany, which deals with the Roman Limes in Franconia (Bavaria) (Flügel \& Schmidt 2013; edufilm und medien $\mathrm{GmbH}$ 2019); the multimedia-augmented reality app 'England's Historic Cities App' | 'England Originals', providing information about selected historical sites in several English cities (England's Historic Cities 2019; Hex Digital Ltd. n.d.; VisitBritain 2019); and the Danish multimedia app 'Digitale Tråde over landskapet' | 'Digital Threads across the Landscape', about archaeological sites and finds from Jutland, which contained augmented reality elements as well (Andersen \& Møbjerg 2013; Møbjerg 2019). ${ }^{2}$ Among the museums in northern Germany, Hamburg Archaeological Museum is exceptionally active in the field of digital outreach programmes, having set up, among others, several mobile exhibition guide applications, a digital 'archaeological window' (showcase) and digital exhibitions (Archäologisches Museum Hamburg 2019). As an international benchmark the British Museum could be named, which - in cooperation with a leading technological brand - has integrated a digital 'discovery centre' for learning in the exhibitions and exploring them with help of digital media (British Museum 2019). Thus, digital and mobile outreach is becoming a key element in the communication of our field.

\footnotetext{
${ }^{1}$ For a review see Malegiannaki and Daradoumis (2017).

${ }^{2}$ Discontinued in 2018 (ibid.).
} 
Yet, the actual didactic benefits of formats like these are seldom evaluated, at least on the basis of didactical research questions or within the framework of educational research (see Degenkolb 2012; Hasberg 2012; Lautzas 2012; Malegiannaki \& Daradoumis 2017). Malegiannaki and Daradoumis published a list of publications (2003-2015) in their review concerning 34 heritage-related mobile spatial games, only seven of which did not report outcomes of user experience or learning (Malegiannaki \& Daradoumis 2017, Appendix C).

However, relative to their vast quantity, very little information about the designing process or the development of outreach programmes in our field of interest is published at all. It is not common to investigate the user's learning outcome. Educational research and publication of evaluation results is necessary, though, in order to:

1. analyse whether the concept of outreach on which a specific outreach programme or its set-up is based actually fulfils the planners' expectations;

2. judge which kind of educational approaches, mediation strategies and media (e.g. videos, audios, texts, pictures, animations, VR, AR) are especially well suited for education with mobile technology - in general and in specific contexts.

Although, for example, download numbers might give insight into the popularity of an application, they do not tell us anything about learning outcome, the users' relationship to the topics mediated and this relationship's development during the use of an outreach format. This is aggravated by the fact that there is no existing theoretical didactical framework for archaeology as opposed to, for example, history (Hasberg 2012; Lautzas 2012; Samida 2010). Even though hints about good practice and didactical frameworks can be derived from other disciplines and fields of research, namely didactics of history and environmental education, it is stated here that the specific nature of archaeological research and sources, of cultural heritage, its remains and management, require educational inquiry in their own right.

\section{Filling the gap - outlines for the integration of didactics}

The deficit outlined so far is not one of technological development but one of communicative and didactic principles. It is caused by developments in research and disciplinary traditions. The obvious, yet not simple, solution is to integrate didactics and findings of educational research into archaeology- and heritage-related educational work. But, as stated before, it is also necessary to implement educational research on these learning opportunities. This can only 
be successful, though, if experts in archaeology or heritage, respectively, work together with experts in educational research and didactics.

The educational opportunities discussed here are forms of scientific or public outreach. In order to set up any kind of outreach format several decisions have to be made (see American Association for the Advancement of Science 2019; Könneker 2012: 2-12).

Probably the most important ones - leaving aside monetary questions concern:

- topics that are to be communicated or communication goals (disciplinary information or political agendas);

- target groups or audience;

- the environment in which communication is to take place;

- the communication tool(s) or means of communication (technology, media, strategies for engagement, didactic approaches).

Even though one format might be suited for communication of a wide range of topics, in most cases the topic - be it results of current archaeological research or a socio-political aim, such as acceptance for heritage protection within the public - determines many of the other aspects (see American Association for the Advancement of Science 2019). Some topics for example might concern only a special audience (e.g. political decision makers) or could not be communicated as well in one place or space as in another. The topic thus stands at the core of our communication. Yet, it is not the key element that facilitates comprehension and thus learning. Educational research has shown that, in order to aid the learning process, it is important to understand the learners' (i.e. the audience's) knowledge and conceptions of the topic in question prior to the communication process (Bell et al. 2009: e.g. 297; Duit et al. 2012; Holfelder 2018; Kattmann et al. 1997; Wehen-Behrens 2014). ${ }^{3}$ This is a prerequisite for the transformation of the scientific or disciplinary information to a level of information comprehensible for the non-expert audience (ibid.). Thus, when developing an outreach or educational programme, we should not ask, 'what do we want to tell our audience?' but 'what is it we want them to understand and how can we approach them?' (see also American Association for the Advancement of Science 2019; Könneker 2012: 5). This forces us to set up explicit learning objectives and to analyse the target group of the planned programme. The learning process can furthermore be facilitated by connections to learners' lived-in world (Bell et al. 2009: e.g. 297; Duit et al. 2012; Holfelder 2018; Kattmann et al. 1997; Wehen-Behrens 2014).

\footnotetext{
${ }^{3}$ This research was mainly conducted in school contexts but its fundamental results are transferred here to a broader sphere of learning (cf. National Research Council 2000: 10-12, 14ff).
} 


\section{'Knowledge transfer in archaeology': science outreach in landscape archaeology}

The approach to science outreach and learning environments outlined so far has been developed as part the author's $\mathrm{PhD}$ project. This project will be described on the following pages as an example for the connection of science outreach, didactic findings, and educational research. Named 'Knowledge transfer in archaeology. A study on the communication of current research content through multimedia learning environments' (working title), it also connects archaeological outreach and digital learning. The project is part of Kiel Science Outreach Campus (KiSOC), a joint project of Kiel University and the Leibniz Institute for Science and Mathematics Education (IPN). Within KiSOC, several researchers from different disciplines are concerned with questions of the principles, effects, development and improvement of science outreach programmes (KiSOC - Kiel Science Outreach Campus 2019). The trans- and interdisciplinary connections of KiSOC provide an important framework enabling a crucial exchange of expertise.

Being rooted in archaeology, the author's project is associated with the Institute of Pre- and Protohistoric Archaeology and the Graduate School 'Human Development in Landscapes' at Kiel University (Kiel University 2019a; 2019b). Fostered by both institutions, archaeological research at Kiel University has been focusing on matters of human-environment interaction and related societal or cultural developments in different periods for more than 10 years. As a consequence, the general topic pursued in the project 'Knowledge transfer in archaeology' was derived from the scope of these institutions' research. It aims to communicate dimensions of human-environment interactions from an archaeological perspective to the public. This focus concerns fundamental issues of human existence, but also ties in well with discussions about environmental issues and sustainability over approximately the last three decades. It therefore inherently bears connections to the lived-in world of present audiences. A second major topic chosen for the project is the character of knowledge dealt with and produced in archaeology. While the question of human-environment interactions lies on a level of disciplinary knowledge and concepts about processes in the past, this second major aspect concerns the ambiguous and imperfect nature of sources as well as the preliminary nature and different levels of certainty of interpretations (see Clark 2004; Clarke 1973; Eggert \& Samida 2013: 50-59; Fulbrook 2002; Trautwein et al. 2017: 15-16). ${ }^{4}$ This second topic thus deals with the very core of production and judgement of

${ }^{4}$ It seems to the author that the theoretical debate about the epistemology of the past and history, strongly kindled by constructivist and postmodern thought, has been much more accounted for in history than in archaeology, even though this debate's basic implications also apply to the latter - which leads to the quotation of several works of historical theoretical literature here. 
scientific knowledge, ${ }^{5}$ and is connected to epistemological theories of research on the past and history.

In practice, these general topics could be addressed in relation to one single archaeological site and/or period. However, the project introduced here follows a diachronic approach in order to explain the heterogeneous development and chronological depths of humans' relationships with their (natural) environment. The audience will follow individual examples from different places and periods, yet within one region in northern Germany. These examples are connected via different sub-topics covering different times and cultures such as food production, the use of natural resources, settlement patterns and burial rites. These 'case studies' also allow for the consideration of challenges or uncertainties connected to the archaeological record and its interpretation.

To take human-environment interactions to a tangible level, landscape constitutes a key concept in the project. This chapter is not the place to define or discuss landscape as a concept - nor environment or nature - but on a local and regional level landscape provides a spatial and cognitive framework in which human interaction with the environment can be placed (see Förster et al. 2012; Kolen, Renes \& Hermans 2015). At the same time the local landscape serves as a link connecting past development, present state and the audience's lived-in world. This is strengthened by the mediation strategy and set-up. As in many other examples (see introduction) an explorative, on-site approach is taken: information will be conveyed in the landscape at places where significant archaeological remains and traces of human or natural impacts on landscape development can be traced. To achieve this, an offline mobile app will be used for the project, which provides the users with GPS-guided cycling tours. While cycling tours (of approximately 25 kilometres) offer an easy way to experience a greater area in short time, mobile app technology forms an up-to-date as well as very flexible tool for communication. Several studies have shown positive effects of outdoor activities on motivation, learning, and general wellbeing (Alon \& Tal 2017; Crawford, Holder \& O'Connor 2017). Crawford, Holder and O'Connor (2017) could, for example, show that mobile applications and personal guided tours are potentially equally effective, at the same time exceeding information boards (interpretive signage). A further argument in favour of the use of mobile technology in outside conditions can be added: it fits the communication habits of young people and has shown positive effects on their motivation in educational contexts (Crawford, Holder \& O'Connor 2017; Medienpädagogischer Forschungsverbund Südwest 2018: 77-80; Molitor 2014). This is of high importance as the main target group defined for the project are children and adolescents between 10 and 15 years. To maintain interest

\footnotetext{
${ }^{5}$ Compare discussions of the 'nature of science' in the natural sciences (Lederman 2007).
} 


\section{Learning Objectives}

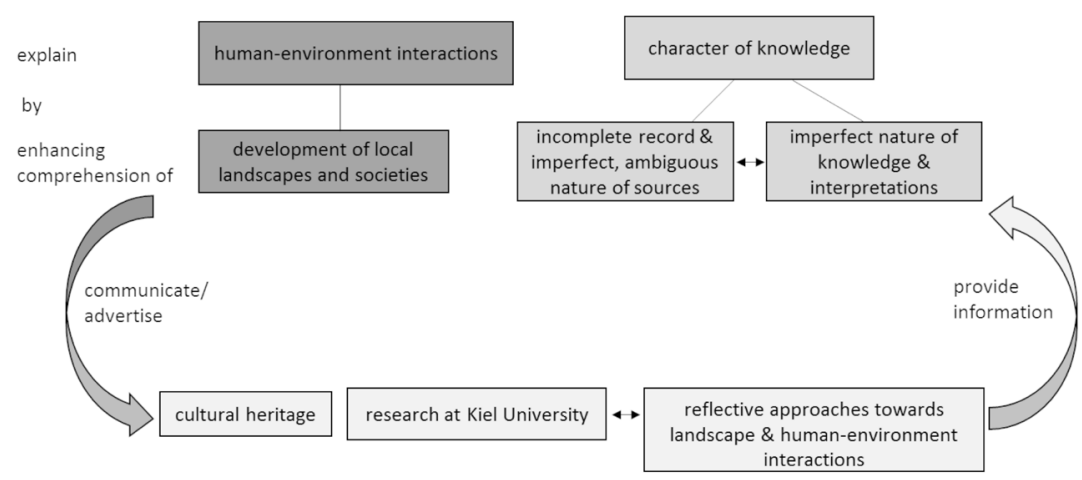

Figure 1: Learning objectives in the project 'Knowledge transfer in archaeology. A study on the communication of current research content through multimedia learning environments' (working title).

and facilitate inquiry-based learning experiences, game elements composed as tasks and challenges will be integrated into the mediation process.

In conclusion, all major decisions in the project 'Knowledge transfer in archaeology' are not only based on disciplinary, technological and practical considerations but rooted in didactic premises. To further strengthen the didactic aspect and to meet the requirements outlined above, the author uses data from semi-structured interviews to discern potential users' conceptions of archaeology and human-environment relations. To enable a systematic selection and transformation of the disciplinary information in accordance with the users' level(s) of knowledge, represented by their conceptions, learning objectives have been developed (Figure 1). They constitute a constant guideline for the development of content. This approach draws on considerations from the 'Model of Educational Reconstruction', developed by Kattmann et al. (1997) and Duit et al. (2012).

From the connection of disciplinary information, users' (or learners') conceptions, learning objectives, practical considerations and communication strategies follow the scheme for content development in the project shown in Figure 2.

In respect of overall methodology, this outreach as well as research project uses design-based research. It integrates theory, development, practice and evaluation and via an iterative design and development process leaves room for adjustments 'on the run' (Raatz 2016; Reinmann 2005). Even though didactic principles and findings from educational research are incorporated into the planning and designing process, the question of effects on the users' 


\section{Developing Content}

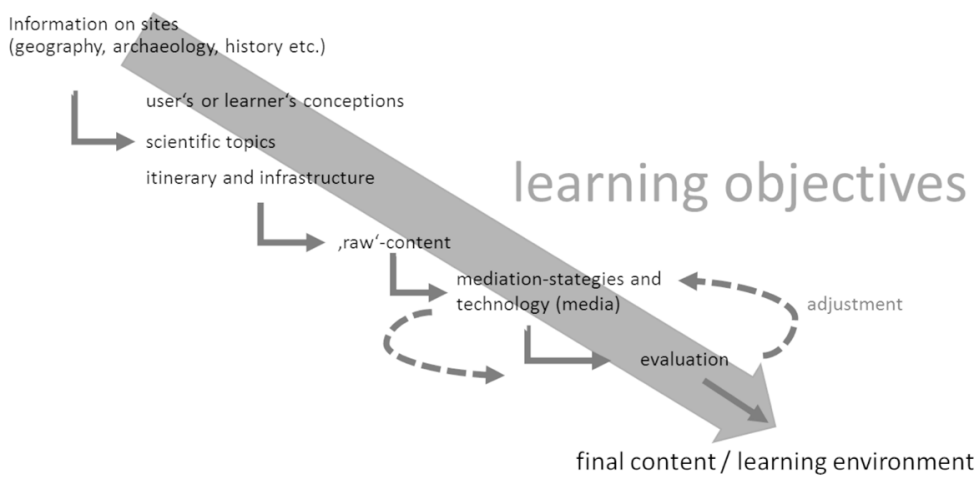

Figure 2: Scheme for the development of content during archaeological outreach outdoors.

learning remains. To actually be able to judge the success of this outreach project, learning achievement will be examined using qualitative methods. Unlike quantitative approaches, they are well suited for an explorative and designbased approach, as qualitative methods leave more room for 'unexpected' findings or ad hoc adjustments and in-depth investigation (Bortz \& Döring 2006: 308-336; Wider 2018: 72). In the framework of design-based research this also means that certain parts of the learning environment might be evaluated before the overall evaluation of learning achievements caused by use of the completed mobile app. Again, learning objectives play a vital part in the research design, as they constitute the standard of comparison. The effectiveness of mobile applications as learning environments should be ensured before they are launched. And, as the research interest thus lies on the effectiveness of this certain type of tool, a design comparing learning achievement with set learning objectives or communication goals seems much more reasonable than test group-control group designs. For a comparison with other media or types of learning environments (e.g. personal guides tours or display boards), on the other hand, other approaches might be more adequate.

\section{Concluding remarks}

This chapter does not aim at marginalising the achievements of practitioners in museum pedagogy, nor those of planners or designers of outreach activities in archaeology and cultural heritage. But if we as archaeologists or heritage managers want to get serious with (science) outreach and (science) education, we have to incorporate didactic principles and results of educational research 
when designing and developing instruments for outreach and science communication. Two important elements are:

1. to set clear/explicit learning objectives;

2. to take the target group's conceptions and prior knowledge into account.

From a disciplinary perspective, a third aspect that should not be neglected is to stay true to the archaeological results and the boundaries of insight in archaeological research. While this should go without saying, in practice there has been a tendency towards too much simplification and overstatement in order to gain public attention. However, as the past cannot be recreated, all our attempts to work out its course and nature are approximations (e.g. Clark 2004; Clarke 1973; Winiwarter \& Knoll 2007: 19-21). Thus, uncertainty stands at the centre of interpretations in our discipline; gaps in our knowledge of the past and the attempts to fill them play a major role in scientific work about the past. These vital circumstances should not be neglected in our public communication but be prominently dealt with - at least as far as time and occasion allow. Marking uncertain parts or levels of uncertainty (of interpretations) and missing information should be able to provoke curiosity, activate learning processes and help non-experts comprehend the nature of our trade.

Furthermore, we have to evaluate our tools of mediation, not only in museum surveys being kept unpublished (as is common practice in Germany), and not only in respect of usability and user satisfaction, but on an empirical, scientific basis considering the learning process. This needs exchange beyond disciplinary borders, including experts from archaeology or cultural heritage, educational research, didactics and educational practice.

\section{References}

Alon, N.L. and Tal, T. (2017). Field trips to natural environments: how outdoor educators use the physical environment. International Journal of Science Education, Part B, 7(3): 237-252.

American Association for the Advancement of Science (2019). Communication Fundamentals. [online] American Association for the Advancement of Science. Available at: https://www.aaas.org/resources/communicationtoolkit/communication-fundamentals [Accessed 22 February 2019].

Andersen, L.R. and Møbjerg, T. (2013). 'Digital Threads across the Landscape' a smartphone application co-developed by users. Archäologische Informationen, 36: 45-53.

Archäologisches Museum Hamburg (2019). Digital Supply. [online] Archäologisches Museum Hamburg. Available at: https://amh.de/en/digital-supply [Accessed 22 February 2019]. 
Bell, P., Lewenstein, B., Shouse, A.W. and Feder, M.A. (2009). Learning Science in Informal Environments: People, Places, and Pursuits, Washington, DC: National Academies Press.

Bonacchi, C. (2014). Understanding the public experience of archaeology in the UK and Italy: a call for a 'sociological movement' in public Archaeology. European Journal of Post-Classical Archaeologies, 4: 377-400.

Bortz, J. and Döring, N. (2006). Forschungsmethoden und Evaluation: für Human- und Sozialwissenschaftler, Heidelberg: Springer-Medizin-Verlag.

British Museum (2019). Samsung Digital Discovery Centre. [online] British Museum. Available at: https://www.britishmuseum.org/learning/samsung centre.aspx [Accessed 22 February 2019].

Clark, E.A. (2004). History, Theory, Text: Historians and the Linguistic Turn. Cambridge, MA: Harvard University Press.

Clarke, D. (1973). Archaeology: the loss of innocence. Antiquity, 47: 6-18.

Crawford, M.R., Holder, M.D. and O'Connor, B.P. (2017). Using mobile technology to engage children with nature. Environment and Behavior, 49(9): 959-984.

Degenkolb, P. (2012). Archäologie, Schule und Museum im Spannungsfeld kultureller Bildung: Einführung in das Tagungsthema. Archäologische Informationen, 35: 89-92.

Duit, R., Gropengießer, H., Kattmann, U., Komorek, M. and Parchmann, I. (2012). The model of educational reconstruction - a framework for improving teaching and learning science. In: D. Jorde and J. Dillon, eds, Science Education Research and Practice in Europe: Retrospective and Prospective, Rotterdam: Sense Publishers, pp. 13-37.

Eggert, M.K.H. and Samida, S. (2013). Ur- und Frühgeschichtliche Archäologie, Tübingen: Francke.

England's Historic Cities (2019). England's Historic Cities. [online] Heritage Cities. Available at: http://www.heritagecities.com/stories/explore [Accessed 22 February 2019].

Flügel, C. and Schmidt, R. (2013). Auf neuen Wegen unterwegs am Limes - Die Smartphone-App 'Limes Mittelfranken Mobil'. Der Limes, 2(7): 36-37.

Förster, F., Großmann, R., Iwe, K., Kinkel, H., Larsen, A., Lungershausen, U., Matarese, C., Meurer, P., Nelle, O., Robin, V., Teichmann, M. (2012). What is landscape? Towards a common concept within an interdisciplinary research environment. eTopoi. Journal for Ancient Studies, [online] 3: 169-179. Available at: http://journal.topoi.org/index.php/etopoi/article/view/124 [Accessed 19 March 2019].

Fulbrook, M. (2002). Historical Theory, London: Routledge.

Hasberg, W. (2012). Kultur - Bildung - Archäologie. Anmerkungen zum Verhältnis von Archäologie und historischem Lernen. Archäologische Informationen, 35: 125-132.

Holfelder, A.-K. (2018). Orientierungen von Jugendlichen zu Nachhaltigkeitsthemen: Zur didaktischen Bedeutung von implizitem Wissen im Kontext $B N E$, Wiesbaden: Springer Fachmedien Wiesbaden. 
Kattmann, U., Duit, R., Gropengießer, H. and Komorek, M. (1997). Das Modell der Didaktischen Rekonstruktion - Ein Rahmen für naturwissenschaftsdidaktische Forschung und Entwicklung. Zeitschrift für Didaktik der Naturwissenschaften, 3(3): 3-18.

Kiel University. (2019a). Human Development in Landscapes. [online] Graduierten Schule. Available at: http://www.gshdl.uni-kiel.de/de [Accessed 24 September 2018].

Kiel University. (2019b). Institute of Pre- and Protohistoric Archaeology. [online] Institut für Ur- und Frühgeschichte. Available at: https://www.ufg.uni-kiel. de/en [Accessed 19 March 2019].

KiSOC - Kiel Science Outreach Campus (2019). KiSOC - Kiel Science Outreach Campus. [online] Available at: http://www.kisoc.de/en [Accessed 22 February 2019].

Kolen, J., Renes, H. and Hermans, R. (eds) (2015). Landscape Biographies: Geographical, Historical and Archaeological Perspectives on the Production and Transmission of Landscapes, Amsterdam: Amsterdam University Press.

Könneker, C. (2012). Wissenschaft kommunizieren: ein Handbuch mit vielen praktischen Beispielen, Weinheim: Wiley-VCH.

Lautzas, P. (2012). Die Archäologie im Bildungswesen in Deutschland. Fragen und Wünsche an die Archäologie aus der Praxis. Archäologische Informationen, 35: 235-236.

Lederman, N. (2007). Nature of science: Past, present, and future. In: S.K. Abell and N.G. Lederman, eds, Handbook of Research on Science Education, London: Routledge, pp. 831-879.

Malegiannaki, I. and Daradoumis, T. (2017). Analyzing the educational design, use and effect of spatial games for cultural heritage: A literature review. Computers \& Education, 108: 1-10.

Medienpädagogischer Forschungsverbund Südwest (2018). [pdf] Available at: https://www.mpfs.de/fileadmin/files/Studien/JIM/2018/Studie/JIM_2018_ Gesamt.pdf [Accessed 19 March 2019].

Møbjerg, T. (2019). 'Digital threads across the Landscape' - a smartphone application involving co-creators. In: T. Møbjerg, L. Ræder Knudsen, H. Rostholm and U. Mannering, eds, The Hammerum Burial site. Customs and Clothing in the Roman Iron Age, Aarhus: Jysk Arkæologisk Selskab \& Aarhus Universitetsforlag.

Molitor, H. (2014). Bildung durch digitale Medien? In: U. Michel, A. Siegmund, W. Ehlers, W. Jahn and A. Bittner, eds, Digitale Medien in der Bildung für nachhaltige Entwicklung: Potenziale und Grenzen, Munich: Oekom Verlag, pp. 25-32.

National Research Council (2000). How People Learn: Brain, Mind, Experience, and School: Expanded Edition. Washington, DC: National Academies Press.

Raatz, S. (2016). Design-based research - Innovation für Bildungswissenschaft und -praxis. In: S. Raatz, ed., Entwicklung von Einstellungen gegenüber verantwortungsvoller Führung: Eine Design-based Research Studie in der Executive Education, Wiesbaden: Springer Fachmedien, pp. 37-61. 
Reinmann, G. (2005). Innovation ohne Forschung? Ein Plädoyer für den Design-Based Research-Ansatz in der Lehr-Lernforschung. Unterrichtswissenschaft, 33(1): 52-69.

Samida, S. (2010). Was ist und warum brauchen wir eine Archäologiedidaktik? Zeitschrift für Geschichtsdidaktik, 9: 215-226.

Trautwein, U., Bertram, C., von Borries, B., Brauch, N., Hirsch, M., Klausmeier, K., Körber, A., Kühberger, C., Meyer-Hamme, J., Merkt, M., Neureiter, H., Schwan, S., Schreiber, W., Wagner, W., Waldis, M., Werner, M., Ziegler, B., Zuckowski, A. (2017). Kompetenzen historischen Denkens erfassen: Konzeption, Operationalisierung und Befunde des Projekts 'Historical Thinking Competencies in History' (HiTCH), Münster: Waxmann.

VisitBritain (2019). England's Originals - Discover England Fund Project. [online] VisitBritain. Available at: https://trade.visitbritain.com/destination-uk/ discover-england-fund/englands-originals [Accessed 22 February 2019].

Wehen-Behrens, B. (2014). 'Früher hat man mit der Umwelt gelebt, heute lebt man über ihr' - SchülerInnenvorstellungen zur Geschichte der Umwelt. In: H. Düselder and A. Schmitt, eds, Umweltgeschichte: Forschung und Vermittlung in Universität, Museum und Schule, Cologne: Böhlau, pp. 191-206.

Wider, M. (2018). 'Man muss es gesehen haben, um es zu verstehen' - Zur Wirkung von historischen Orten auf Schülerinnen und Schüler, Hamburg: Dr. Kovač.

Winiwarter, V. and Knoll, M. (2007). Umweltgeschichte. Eine Einführung, Cologne: Böhlau.

\section{Ludography}

Limes Mittelfranken Mobil (2019). edufilm und medien GmbH. [Android]. England Originals (n.d.). Hex Digital Ltd. [Android]. 